UDC: 785.6

\title{
Ira Prodanov*
}

University of Novi Sad

Academy of Arts

\section{THE RETURN OF THE BAROQUE: CONCERTO DRAGONESE BY DRAGANA JOVANOVIĆ 1}

\begin{abstract}
That "past is altered by the present as much as the present is directed by the past" (T. S. Eliot) is confirmed in Concerto Dragonese, a new piece by Dragana Jovanović, dedicated to the thirtieth anniversary of the existence of the Camerata Academica Ensemble of the University of Novi Sad Academy of Arts. Composed as a typical concerto grosso, it reflects the theoretical foundations of French thinker Guy Scarpetta and the thoughts of American art historian Gregg Lambert on the return of the Baroque to the very center of contemporary creative activity, but also into the very style of life that is today. This, however, does not deprive the piece from the 'Benjaminian aura', which allows it to communicate through various references to baroque masters and rhythms of contemporary popular genres of dances, film music and the like.
\end{abstract}

Keywords: Concerto Dragonese, concerto grosso, Baroque, popular culture

\footnotetext{
* Author contact information: iraprodanovkrajisnik@gmail.com

1 This text is the result of a scientific production related to the project entitled Cultural Identities in Artistic Production of the University of Novi Sad Academy of Arts - Archiving and Analytical Representation of Corpus and Tradition financed by the Provincial Secretariat for Science and Technological Development, No. 114-451-1671/2016-02.
} 
"What happens when a new work of art is created", writes Thomas Stearns Eliot in the essay entitled Tradition and the Individual Talent, "is something that happens simultaneously to all the works of art which preceded it. The existing monuments form an ideal order among themselves, which is modified by the introduction of the new (the really new) work of art among them". ${ }^{2}$ At the very section, the British poet points out that "tradition involves, in the first place, the historical sense [...] and the historical sense involves a perception, not only of the pastness of the past, but of its presence. [...] The past is altered by the present as much as the present is directed by the past".3 It is precisely on the trail of Eliot's claims that a new piece by Dragana Jovanović entitled Concerto Dragonese, dedicated to the thirtieth anniversary of the founding of the Camerata Academica Ensemble of the University of Novi Sad Academy of Arts, ${ }^{4}$ can be listened to, interpreted and analyzed.

2 Tomas Stern Eliot, Tradicija i individualni talenat. Eseji, Beograd, Službeni glasnik, $2017,11$.

3 Ibid.

4 Camerata Academica is a chamber ensemble that has been operating within the University of the Novi Sad Academy of Arts since 1988. The orchestra members are the best young musicians of the Academy of Arts - assistant and associate professors and the most talented students. Thus, some of the former Camerata's members are now prominent soloists and members of prestigious European orchestras (Julija Hartig, Peđa Milosavljević, Dejan Bogadnović, Zorica Stanojević and many others). Camerata Academica has collaborated with numerous highly renowned national and foreign soloists, and performed under the artistic leadership of violoncellist Ištvan Varga in all major cities of the former Yugoslavia; they have had successful appearances in Germany (Dortmund) and the Netherlands (Amsterdam) and have participated in significant music events (BEMUS, NOMUS, the Ohrid Summer Festival, the International Composers' Forum, the Budva Theatre City Festival...), realising, as well, a large number of permanent radio and television recordings. On their repertoire, Camerata always nurtured national compositional creativity. The orchestra operated with success until the end of 1999, when, due to the political crisis that forced many musicians to leave the country, they ceased their work. At the end of 2007, on the initiative of cellist Marko Miletić, the orchestra was built up again. Performing at concerts the most demanding pieces of the art music repertoire, as well as pieces by national composers, Camerata has achieved a great deal of success, appearing with distinguished soloists (Stefan Milenković, Wendy Warner, Dejan Mlađenović, Imre Kalman, Peđa Milosavljević, Boštjan Lipovšek, Julija Hartig). The ensemble receives positive reviews in which the beauty of the sound and the remarkable expression are always emphasised. Soon after the reestablishment of the orchestra, RTV Vojvodina offered them the possibility of doing a studio recording of each performed piece. 
It is no coincidence that Dragana Jovanović has specifically chosen concerto grosso as a framework of the composition commissioned by the ensemble which was established, as one of the key artistic bodies of the Academy of Arts in Novi Sad, by cellist Ištvan Varga in the late eighties. From the very beginning, Camerata has been a symbol of the institution within which it was founded. Its members have always been distinguished students and professors of the Academy, and because of its quality, the ensemble visited the former Yugoslav region by participating in the most important festivals. According to the founder's very comments, there was even a healthy rivalry between this chamber ensemble and the Symphony Orchestra of the Academy of Arts, so members of the Camerata were called "Vargists". Even that aura of specialty and excellence, as evidenced by numerous critiques, suggests that the musicians of this ensemble - just like at the time of the appearance of concert in the $17^{\text {th }}$ century - "moved in harmony with each other [...] because the first real concerts did not originate from the desire for virtuosity, but for the joy of sound". 6 The choice of the concerto grosso form covered, therefore, everything that Camerata essentially is, and the given data have to be accepted as the semiotic context of all its possible interpretations (not only musical), "because that is how the depth of a specifically artistic meaning is achieved, and its life extended".

According to the composer, the title of the piece refers to several possible meanings. The first is related to a "drago" (it.) or "dragon", and it could be understood as 'extremely virtuoso', because in Serbian colloquial speech, it is often said of one who plays well that they play 'like a dragon'. The second reference to the term "dragonese" the composer relates to the Dragone, a river in Italy, "the country of Vivaldi". "Finally, there is also "a coincidence in the pronunciation of the name Dragana, which people of the non-Balkan region most often pronounce as Dragona". ${ }^{9}$ Different 'readings' of the composition's title also suggest a diverse 'listening' to the music that the composer says is based on the pluralism of styles and genres. The multi-meaning title of the

5 Ira Prodanov, Nataša Crnjanski, Nemanja Sovtić, Mixed Choir and Simphony Orchestra of the Academy of Arts University of Novi Sad, Novi Sad, Akademija umetnosti, 2019, 39.

6 Roksanda Pejović, Barokni koncert, Beograd, Nolit, 1982, 12.

7 Nataša Crnjanski, Prokofjev i muzički gest, Novi Sad, Akademija umetnosti, 2014, 34.

8 From the correspondence with the composer in November 2018.

9 Ibid. 
piece thus resonates with the diversity of its musical language, in which Dragana Jovanović creates a wide range of music associations that allow the listener to 'choose' in Barthes's way the time and compositional means through which they 'hear' the Concerto Dragonese. For, "if a piece of music is seen [...] as an open message that can be given more possible meanings, or in which at the same time different meanings can coexist, we cannot be satisfied with only one verbal translation that limits its possible semantic range". ${ }^{10}$

Example 1: Dragana Jovanović, Concerto Dragonese, I movement, Energico, b. 1-5

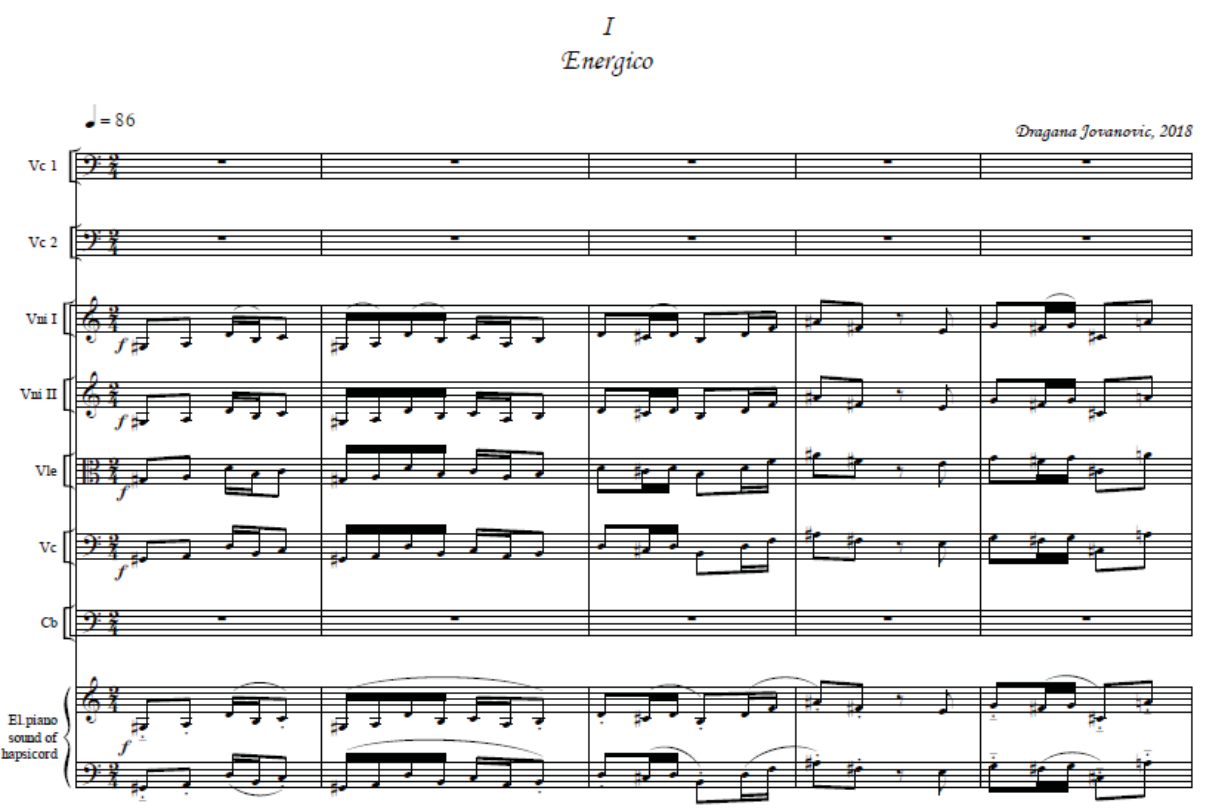

Concerto Dragonese is a concerto for two cellos, string orchestra and electric piano with the sound of the harpsichord (obligatory instrument). It is a "concerto grosso in the full sense of the word"11 in which the technically demanding sections of two solo cellos, separately or in two-part playing, compete with relatively clear and simple orchestra parts, which, however, have very subtly determined agogic and dynamic marks. All the characteristic elements of concerto grosso are present, dialogues based on the same thematic materials that 'rise' from one core, the concertare principle between the two

10 Joseph P. Swain, Musical Languages, New York, W. W. Norton, 1997, 84.

11 Ibid. 
soloists, or between them and the orchestra, as well as the solo cadences in each of the three movements. The first movement Energico sounds especially baroque with its unison from the beginning, resembling the beginning of Bach's Concerto for Harpsichord and Orchestra in D Minor, BWV 1052, while the ripieno 'answer' is the echo of the famous answer from the Concerto for Violin and Oboe in C Minor BWV 1060, shifted to the first beat. However, this is just one possible listening because "someone will hear Monteverdi, someone Bach, and someone Vivaldi". ${ }^{12}$

Example 2: D. Jovanović, Concerto Dragonese, Arioso, Molto legato e espressivo, b. 8-12

10

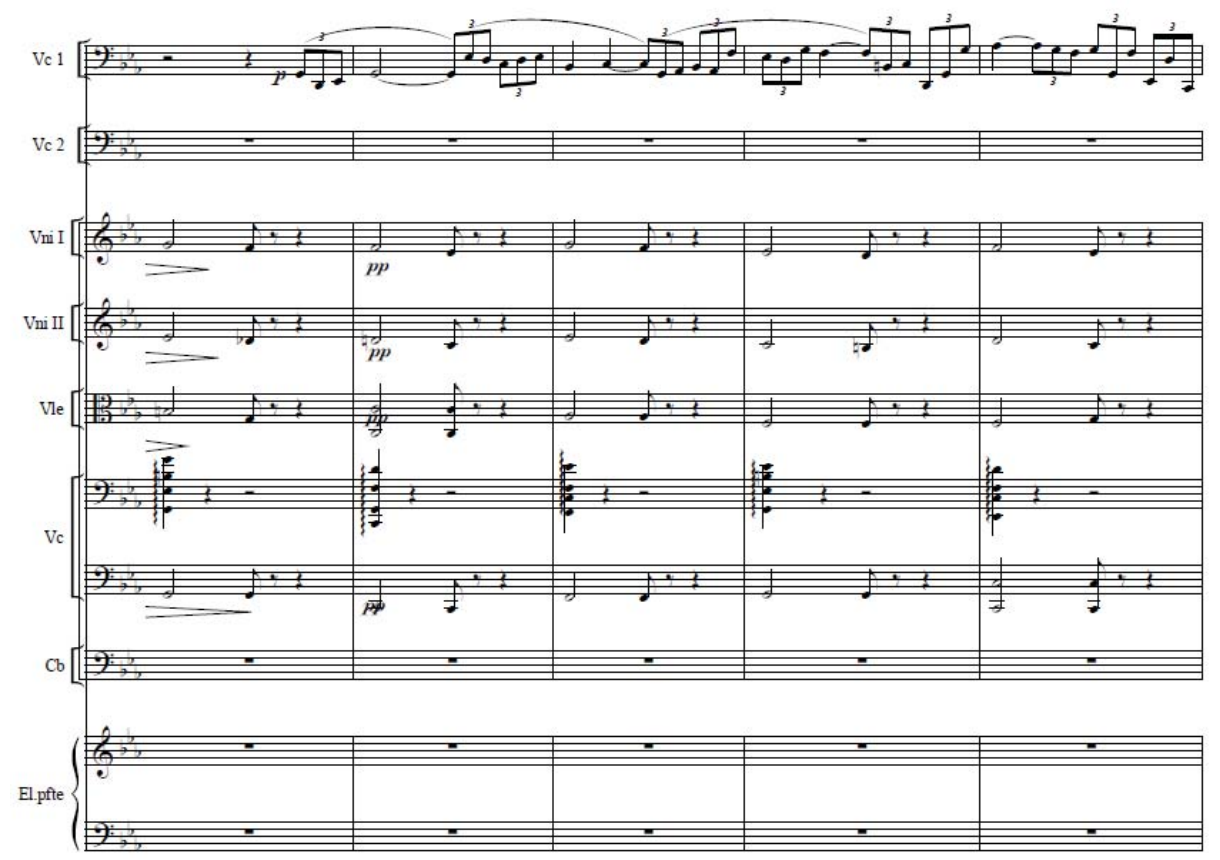

The first movement also contains a typical baroque harmonic progression in the dominant key, which the composer calls a "fifth or dominant level", ${ }^{13}$ as well as a Vivaldian multiple repetition of the main theme, and the

12 Ibid.

13 Ibid. Sound examples are available online at the official New Sound YouTube channel: https://youtu.be/DicYjQrfKKY. 
return to the initial tonal center in a. The second movement, Arioso, is made of three musical slurs of one and the same theme, each of them increasing in dynamics, becoming richer in polyphony and orchestration, and which are framed with an introduction and coda.

Example 3: D. Jovanović, Concerto Dragonese, Allegro con brio, Energico, b. 101

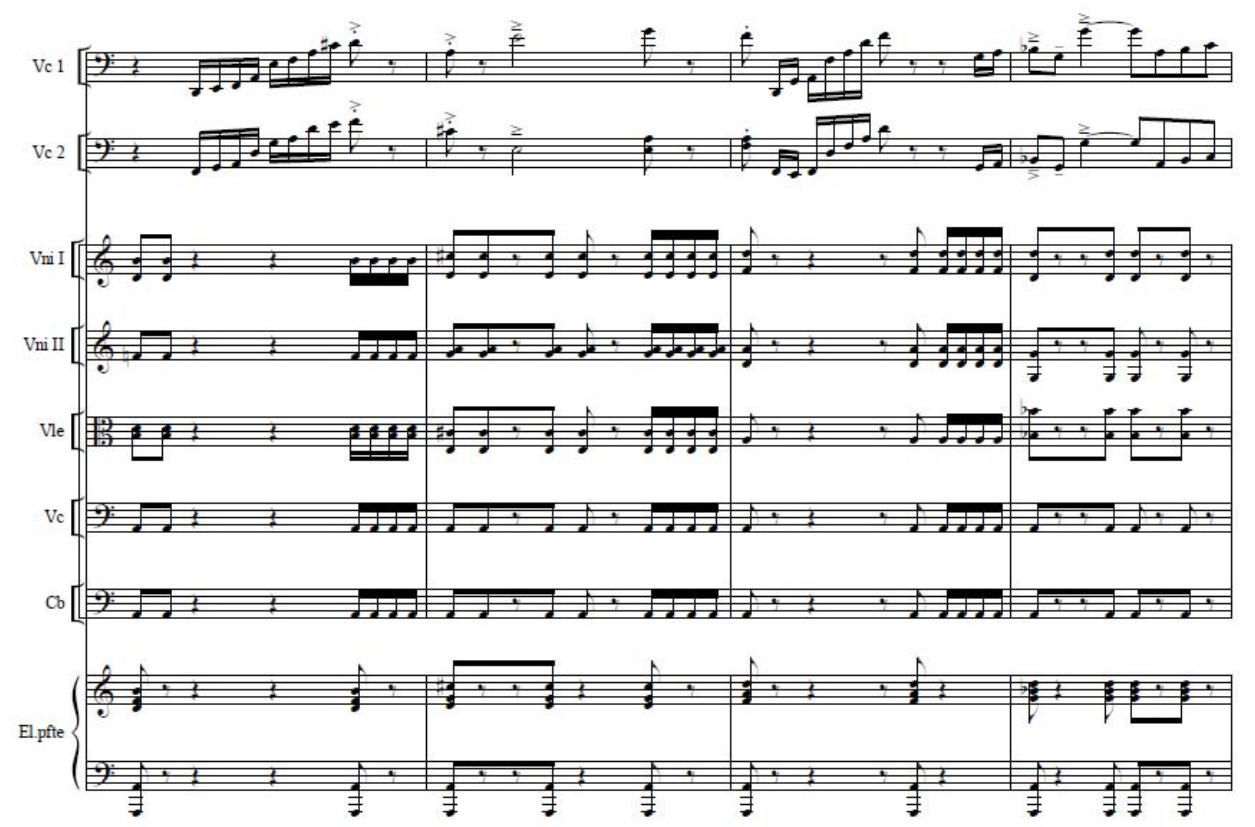

The vividness of their gradation gives this musical content something of the distressing atmosphere in the Williams' music theme from the Schindler's List movie (1993), although there is no specific similarity of motifs. And, the composer's ability is noticeable right here in connecting various postmodern combinations of styles and genres, which encourages listeners to seek for associations in the entire opus of their own musical experience. That ability also reflects a Milhaudean belief in the significance of the melody in the classical sense of the word, which will fix the piece in one's memory ${ }^{14}$ because in this movement, the melody is an absolutely dominant musical element, 'softened' and sustained by the 'rounded' effects of the triplet rhythm.

14 Ira Prodanov, Istorija muzike 20. veka, Novi Sad, Akademija umetnosti, 2013, 37. 
Finally, the third movement, Allegro con brio, extremely virtuoso, with a dose of the energy of an extravagant tango-like gesture, even more closely corresponds with the baroque compositional techniques, among which are, explicitly, the effects of building harmonic sequences.

Although different musical pasts are met in Concerto Dragonese, the Baroque seems to be the most dominant one. However, it is not just about restoring the neo-baroque composing style, as was the case at the beginning of the 20th century in Western Europe. According to the French theoretician of art, Guy Scarpetta, the word is that "we live the period of Baroque", 15 and that it is possible to speak of the return of the "Baroque trait to the very center of modern creativity". ${ }^{16}$ Namely, the Baroque introduces a "tremendous relief [...] general enjoyment and arbitrariness [...] a world in which the mask is more truthful than the face it hides [...] where the other side of a décor is another décor". ${ }^{17}$ The Baroque also represents the period in which "illusion is designated as such, where the spectacle is accepted, doubled, where what is represented already belongs to the line of representations, where beyond the fiction there is always another fiction [...]". ${ }^{18}$ The use of social networks such as Facebook or Instagram today, where the displayed contents most likely represent the 'best' part of the personality that creates the profile, the worship of the body with a dramatic increase in the number of surgical interventions that enlarge or change its parts, the use of excessive accessories, artificial eyelashes, artificial eyebrows, a wardrobe in which zircon and diamonds are the highlight of beautification - all this speaks of the society of "hyper-theatralization" that lies behind the scenes of its fictional realities, in which "the illusion is combated by the very processes of creating an illusion". ${ }^{19}$ And not just that: the extreme (public) display of feelings, the most diverse spectacles in which "what appears is good; what is good appears", ${ }^{20}$ testifies to a new understanding of emotions, to the need to 'expose' them to the limits of stamina, especially in the media. The French scholar reads such a "burning with excitement, feeling of trembling, restlessness, enthusiasm, exhilaration", in baroque

15 Gi Skarpeta [Guy Scarpetta], Povratak baroka, Novi Sad, Svetovi, 1988, 10.

16 Ibid., 10.

17 Ibid., 21.

18 Ibid., 17.

19 Ibid., 16.

20 Guy Debord, Theory of Spectacle shttp://www.antiworld.se/project/references/texts/ The_Society\%20_Of\%20_The\%20_Spectacle.pdf 
art, emphasising its tendency to "excessiveness, some kind of vertigo that directly turns to the body and whose effect could refer to a term that is both secular and sacred - the ecstasy". ${ }^{21}$ What is unusual in that ecstasy is that it is not 'natural', but is caused by a play of shapes, codes, styles - by the artistic skill. ${ }^{22}$ It is precisely this play of codes that is recognised and applied by Dragana Jovanović, achieving the effect of identifying with the culture of the Baroque, well-known and recognised, wrapped in the common Benjaminian aura, but now with the aura of contemporaneity that gives her the incredible freedom of interpretation. Or, as Thomas Bernhard says, "it is not about developing a story, but about wrapping it". ${ }^{23}$ An additional argument for such interpretations of the Concerto Dragonese is given by American scientist Gregg Lambert. This American scientist sees the return of the Baroque even where the Baroque never existed, in the island countries, in the Caribbean, in the areas that had their own autochthonous culture and, within it, their musical tradition independent of the European or the Baroque-European one. Lambert's orientation to the Baroque as a "global phenomenon in the modern world", 24 which is why he wants to talk about it in the plural ("there are many baroques"25), explains why audiences from different parts of the world today 'eagerly' look at contemporary works based on baroque poetics. There is something - states Lambert - that contributes to the fact that the Baroque has restored some impression of 'timelessness' thanks to abandoning the linear understanding of history and the theory of the acceleration of time that allows movement 'through it' in all directions.

It should not be forgotten that the Baroque 'became involved' in the popular music of the second half of the 20th century. Songs such as In My Life by the Beatles, A Whiter Shade of Pale by Procol Harum, or Angel in My Heart by Mick Jagger, invoke elements of the baroque style in various ways, indicating the popular culture's tendency to absorb the elements of high and low culture and offer 'solutions' that - even according to the English theoreticians, that is culturalists, such as Hall, Fiske and Williams - express the creativity of the current state of culture, and not something random, 'less valuable' and ephemeral.

\footnotetext{
${ }^{21}$ Gi Skarpeta, op. cit., 19.

22 Ibid.

23 Tomas Bernhard, Brisanje. Raspad, Beograd, Lom, 2014.

24 Gregg Lambert, The Return of the Baroque in Modern Culture, London, Continuum, 2004, 23.

25 Ibid.
} 
Concerto Dragonese by Dragana Jovanović precisely represents such a creative result in which the communication primarily between the performers and then the audience is achieved by the known (baroque) elements of an equivocal tonality, buoyant rhythm and rich melodic potential, and not because of the eagerness for technical perfectionism of demanding sections, but precisely because of that "joy of sound", pointed out by Roksanda Pejović.

\section{Works cited}

Bernhard, Tomas: Brisanje. Raspad. Beograd: Lom, 2014.

Crnjanski, Nataša: Prokofjev i muzički gest. Novi Sad: Akademija umetnosti, 2014.

Debord, Guy: Theory of Spectacle internet link shttp://www.antiworld.se/project/references/texts/The_Society\%20_Of\%20_The\%20_Spectacle.pdf

Eliot, Tomas Stern: Tradicija i individualni talenat. Eseji. Beograd: Službeni glasnik, 2017.

Lambert, Gregg: The Return of the Baroque in Modern Culture. London: Continuum, 2004.

Pejović, Roksanda: Barokni koncert. Beograd: Nolit, 1981.

Prodanov, Ira: Istorija muzike 20. veka. Novi Sad: Akademija umetnosti, 2013.

Prodanov, Ira, Crnjanski, Nataša i Sovtić Nemanja: Mixed Choir and Symphonu Orchestra of the Academy of Arts University of Novi Sad. Novi Sad: Akademija umetnosti, 2019.

Skarpeta, Gi: Povratak baroka. Novi Sad: Svetovi, 1988.

Swain, Joseph P.: Musical Languages. New York: W. W. Norton, 1997.

\section{Summary}

That "past is altered by the present as much as the present is directed by the past..." (T. S. Eliot) is confirmed in Concerto Dragonese, a new piece by Dragana Jovanović, dedicated to the thirtieth anniversary of existence of the Camerata Academica Ensemble of the University of Novi Sad Academy of Arts. Composed as a typical concerto grosso, it reflects the theoretical foundations of French thinker Guy Scarpetta and the thoughts of American art historian Gregg Lambert on the return of Baroque to the very center of contemporary creative activity, but also into the very style of life that is today. This, however, does not deprive the piece from the 'Benjaminian aura', which allows it to communicate through various references to baroque masters and rhythms of contemporary popular genres of dances, film music and the like. 
Чланак примљен 3. марта 2019. Чланак прихваћен 16. маја 2019.

\author{
Ира Проданов* \\ Универзитет у Новом Саду \\ Академија уметности
}

\title{
ПОВРАТАК БАРОКА: CONCERTO DRAGONESE ДРАГАНЕ JOВАНОВИҢ ${ }^{1}$
}

\begin{abstract}
Апстракт: Да „садашњост исто толико мења прошлост, колико прошлост управља садашњошћу“ (Т. С. Елиот) потврђује ново дело Драгане Јовановић Concerto Dragonese посвећено тридесетогодишњици постојања ансамбла Camerata academica Академије уметности Универзитета у Новом Саду. Компоновано као типичан concerto grosso оно одсликава теоријске поставке француског мислиоца Ги Скарпете (Scarpetta) и ставове америчког историчара уметности Грега Ламберта о повратку барока у само средиште савременог стваралаштва, али и у сам стил живота која се данас води. То међутим дело не лишава „бењаминске ауре“ која омогућава да оно комуницира кроз различите асоцијације на барокне мајсторе и ритмове савремених популарних жанрова плеса, филмске музике и слично.

Кључне речи: Concerto dragonese, concerto grosso, барок, популарна култура
\end{abstract}

“Оно што се догађа кад се створи неко ново уметничко дело“, пише Томас Стерн Елиот (Thomas Stearns Eliot) у есеју Традиција и индивидуални таленат, ,jе нешто што се у исти мах дешава и са свим уметничким делима која су му претходила. Постојећи споменици образују међу собом један идеалан поредак који се модификује увођењем новог (уистину новог) уметничког дела““2 На истом месту, британски песник истиче да „традиција на првом месту обухвата осећање историје [...] а то осећање укључује запажање не само онога што је прошло у прошлости, већ и што је садашње у прошлости [...] Садашњост исто толико мења прошлост, колико прошлост управља садашњошћу“.3 Управо на трагу Елиотових тврдњи може се слушати, тумачити и анализирати ново дело Драгане Јовановић под називом Concerto dragonese, посвећено тридесетогодишњици оснивања ансамбла Camerata academica Академије уметности Универзитета у Новом Саду. ${ }^{4}$

\footnotetext{
* Ауторкина контакт адреса: iraprodanovkrajisnik@gmail.com

${ }^{2}$ Tomas Stern Eliot, Tradicija i individualni talenat. Eseji, Beograd, Službeni glasnik, 2017, 11.

${ }^{3}$ Ibid.

${ }^{4}$ Camerata academica је камерни аснамбла који делије у оквиру Академије уметности Универзитета у Новом Саду од 1988. године. Чланове оркестра чине најболји млади музичари Академије уметности асистенти доценти, и најталентованији студенти. Тако су неки од бивших чланова Caтеrate сада угледни солисти и чланови престижних европских оркестара (Јулија Хартиг, Пеђа Милосављевић, Дејан Богадновић, Зорица Станојевић и многи други). Camerata Academica је сарађивала са бројним домаћим и иностраним солистима високог реномеа, а под уметничким руководством виолончелисте Иштавана
} 
Није случајно што је Драгана Јовановић одабрала управо concerto grosso као оквир за садржај композиторске наруџбине ансамбла којег је, као једно од кључних уметничких тела Академије уметности у Новом Саду, основао виолончелиста Иштван Варга крајем осамдесетих година прошлог века. Camerata је од самих почетака била заштитни знак институције на којој је настала. Њени чланови увек су били истакнути студенти и професори Академије, а ансамбл је због свог високог квалитета обишао некадашњи југословенски регион учествујући на најважнијим фестивалима. Према коментарима самог оснивача, постојала је чак здрава конкуренција између овог камерног састава и Симфонијског оркестра Академије уметности, па су се чланове камерате називали „Варгистима“. 5 Већ и та аура посебности и изврсности, о којој сведоче бројне критике, указује на то да су се музичари овог састава - баш као у време настанка концерта у XVII веку - „кретали у складу један са другим [...] јер први прави концерти нису настали из жеље за виртуозитетом, већ због радости звучног деловања“. 6 Избор форме concerta grossa обухватио је, дакле, све оно што Camerata суштински јесте, а наведени подаци морају се прихватити као семиотички контекст свих његових могућих интерпретација (не само музичких), ,jер се на тај начин досеже дубина специфично уметничког значења, али и продужава његов живот“. 7

Назив дела, према речима ауторке, реферише на неколико могућих значења. Прво асоцира на drago (ит.) или dragon (енг.) - змај, и могло би да се разуме као 'изузетно виртуозно', јер се у српском колоквијалном говору често за оног који одлично свира каже да свира 'као змај'. Другу асоцијацију на термин “dragonese” ауторка везује са за реку Драгоне у Италији, ,земљу Вивалдија“. ${ }^{8}$ Коначно, присутна је и „случајна подударност у изговору имена Драгана, које особе небалканског подручја најчешће изговарају као ‘Драгона'“.9 Различита 'читања' наслова дела наговештавају и различита 'слушања' музике за коју композиторка каже да је ослоњена на плурализам стилова и жанрова. Вишезначни наслов дела тако резонира и са вишезначношћу његовог музичког језика у којем Драгана Јовановић ствара широки круг музичких асоцијација које дозвољавају слушаоцу да сам бартовски 'одабере' време и композициона средства кроз које Concerto dragonese 'чује'. Јep, ,,ако музичко дело [...] видимо као отворену поруку којој је могуће дати више могућих значења, или у којима

\footnotetext{
Варге наступала је у свим већим градовима бивше Југославије, остварила успешна гостовања у Немачкој (Дортмунд) и Холданији (Амстердам) и учествовала и на значајнијим музичким манифестацијама (БЕМУС, НОМУС, Охридско лето, Међународна трибина композитора, Град-театар Будва...), а такође је остварила и велики број трајних радијских и телевизијских снимака. На свома репертоару Camerata је увек неговала и домаће композиторско стваралаштво. Оркестар са успехом делује до краја 1999. године, када, због политичке кризе која је бројне уметнике приморала да напусте земљу, престаје са радом. Крајем 2007. године на иницијативу виолончелисте Марка Милетића оркестар бива обновљен. Изводећи на концертима најзахтевнија дела класичног репертоара као и дела домаћих композитора, $\underline{\text { Camerata }}$ бележи бројне успехе наступајући с угледним солистима (Стефан Миленковић, Wendy Warner, Дејан Млађеновић, Имре Калман, Пеђа Милосављевић, Боштијан Липовшек, Јулија Хартиг). Ансамбл добија позитивне критике у којима се увек истиче лепота тона и упечатљив израз. РТВ Војводина убрзо по поновном оснивању оркестра нуди могућност студијског снимања сваког изведеног дела.

${ }^{5}$ Ira Prodanov, Nataša Crnjanski, Nemanja Sovtić, Mixed Choir and Simphony Orchestra of the Academy of Arts University of Novi Sad, Novi Sad, Akademija umetnosti, 2019, 39.

${ }^{6}$ Roksanda Pejović, Barokni concert, Beograd, Nolit, 1982, 12.

${ }^{7}$ Nataša Crnjanski, Prokofjev i muzički gest, Novi Sad, Akademija umetnosti, 2014, 34.

${ }^{8}$ Из преписке са ауторком новембра 2018.

${ }^{9}$ Ibid.
} 
могу коегзистирати истовремено различита значења, не можемо се задовољити само једним вербалним преводом који ограничава његов могући семантички распон““ ${ }^{10}$

Concerto dragonese је концерт за два виолончела, гудачки оркестар и електрични клавир са звуком чембала (облигатни инструмент). То је „concerto grosso у пуном смислу те речи" 11 у којем се технички захтевне деонице два соло виолончела, посебно или у двогласју, надмећу са релативно јасним и једноставним деоницама оркестра, које међутим имају веома суптилно одређене агогичке и динамичке ознаке. Присутни су сви карактеристични елементи concerta grossa, дијалогизирање на основу истих тематских целина које 'израстају' из једног језгра, concertare принцип између двају солиста, или између њих и оркестра, као и солистичке каденце у сваком од три става. Посебно барокно звучи први став, Energico, чији унисоно са почетка подсећа на почетак Баховог (Bach) Кониерта за чембало и оркестар у д молу, BWV 1052, док је 'одговор' рипиена ехо чувеног одговора из Концерта за виолину и обоу у це молу BWV 1060, пребачен на прву добу. Међутим, то је само једно од могућих слушања, јер ће „неко чути Монтевердија, неко Баха, а неко Вивалдија““. ${ }^{12}$

Пример 1: Д. Јовановић, Concerto Dragonese, први став, Energico, т. 1-5

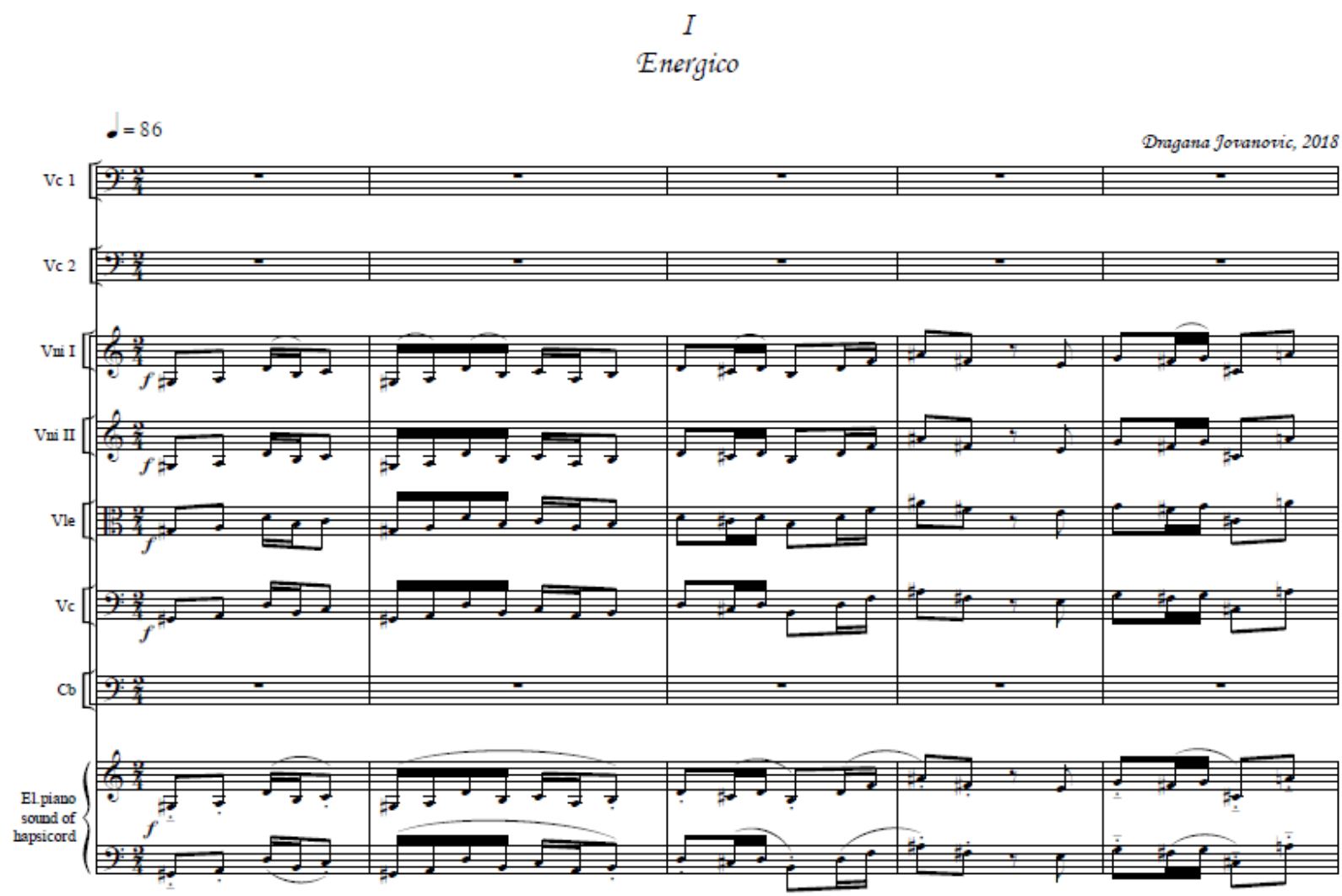

\footnotetext{
${ }^{10}$ Joseph P. Swain, Musical Languages, New York, W. W. Norton, 1997, 84.

${ }^{11}$ Ibid.

${ }^{12}$ Ibid.
} 
Први став такође садржи и типично барокно хармонско вођење у доминантни тоналитет које ауторка назива „квинтним или доминантним нивоом“, ${ }^{13}$ као и вивалдијевско вишеструко понављање главне теме, те повратак на почетни тонални центар in a. Други став, Arioso, саткан је од три музичка лука једне исте теме, од којих је сваки у све јачој динамици, пунијој полифонији и оркестрацији, а које уоквирују увод и кода.

Пример 2: Д. Јовановић, Concerto Dragonese, Arioso, Molto legato e espressivo, т. 8

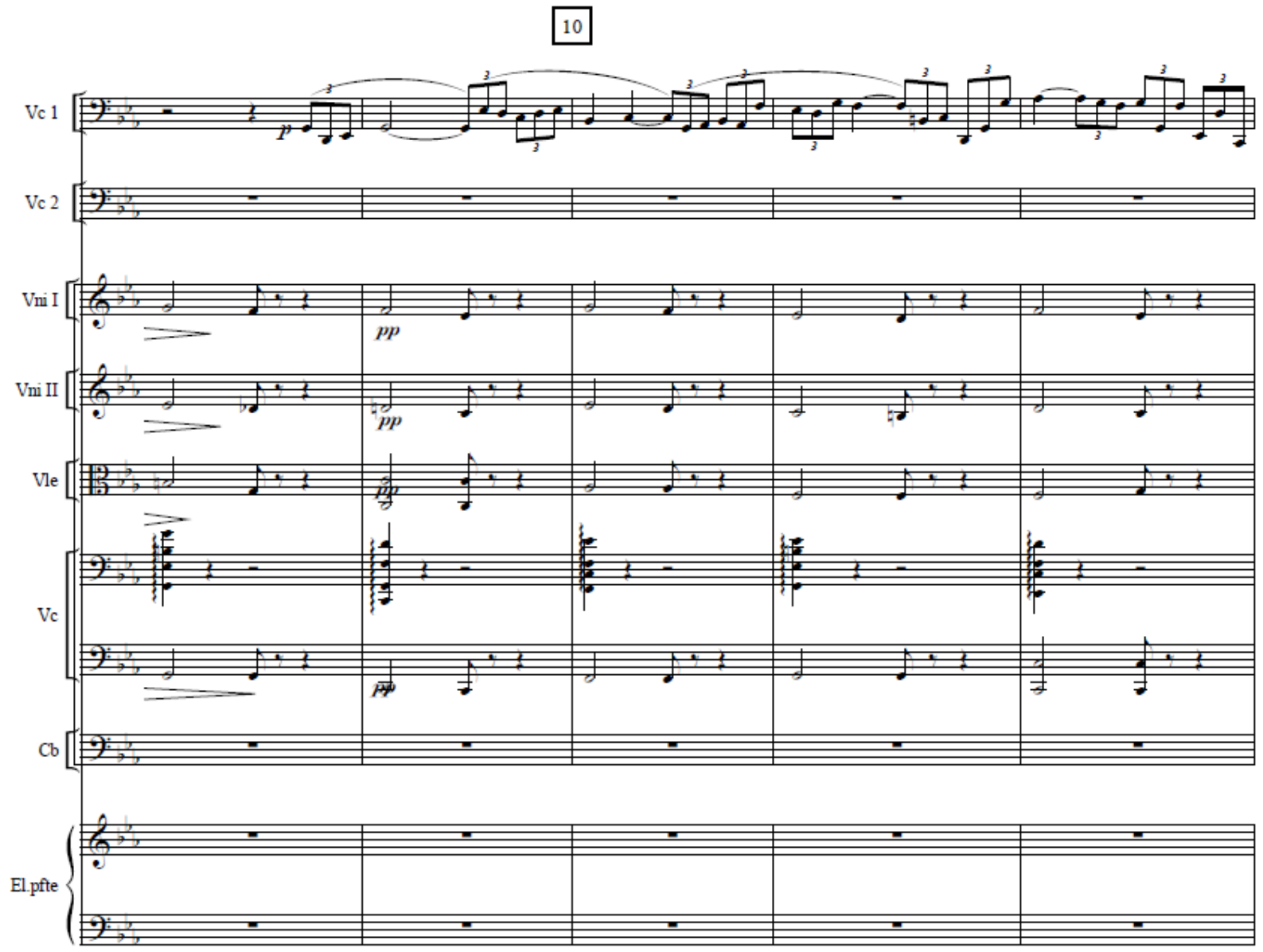

Упечатљивост њихове градације даје овом музичком садржају нешто од потресне атмосфере насловне теме Вилијамсове (Williams) музике из кинематографског остварења Шиндерова листа (Schindler's List, 1993), премда конкретне мотивске сличности нема. И управо ту је уочљива ауторкина умешност умрежавања различитих постмодернистичких комбинација стилова и жанрова која подстиче слушаоца на трагање за асоцијацијама у укупном опусу сопственог музичког искуства. Та умешност одражава и оно мијоовско уверење о значају мелодије у класичном смислу речи, захваљујући којој ће дело остати упамћено. ${ }^{14}$ Јер у овом ставу је мелодија апсолутно

\footnotetext{
${ }^{13}$ Ibid. Звучни примери доступни су на званичном YouTube каналу Новог звука: https://youtu.be/DicYjQrfKKY .

${ }^{14}$ Ira Prodanov, Istorija muzike 20. veka, Novi Sad, Akademija umetnosti, 2013, 37.
} 
доминантни музички елемент, 'смекшана' и испевана ефектима 'облог' триолског ритмичког покрета.

Коначно, трећи став, Allegro con brio, изузетно виртуозан, са дозом енергије екстравагантног геста једног танга, још изразитије кореспондира са барокним техникама стварања, међу којима посебно јасно са ефектима изградње хармонски условљених секвенци.

Пример 3: Д. Јовановић, Concerto Dragonese, Allegro con brio, Energico, т. 101

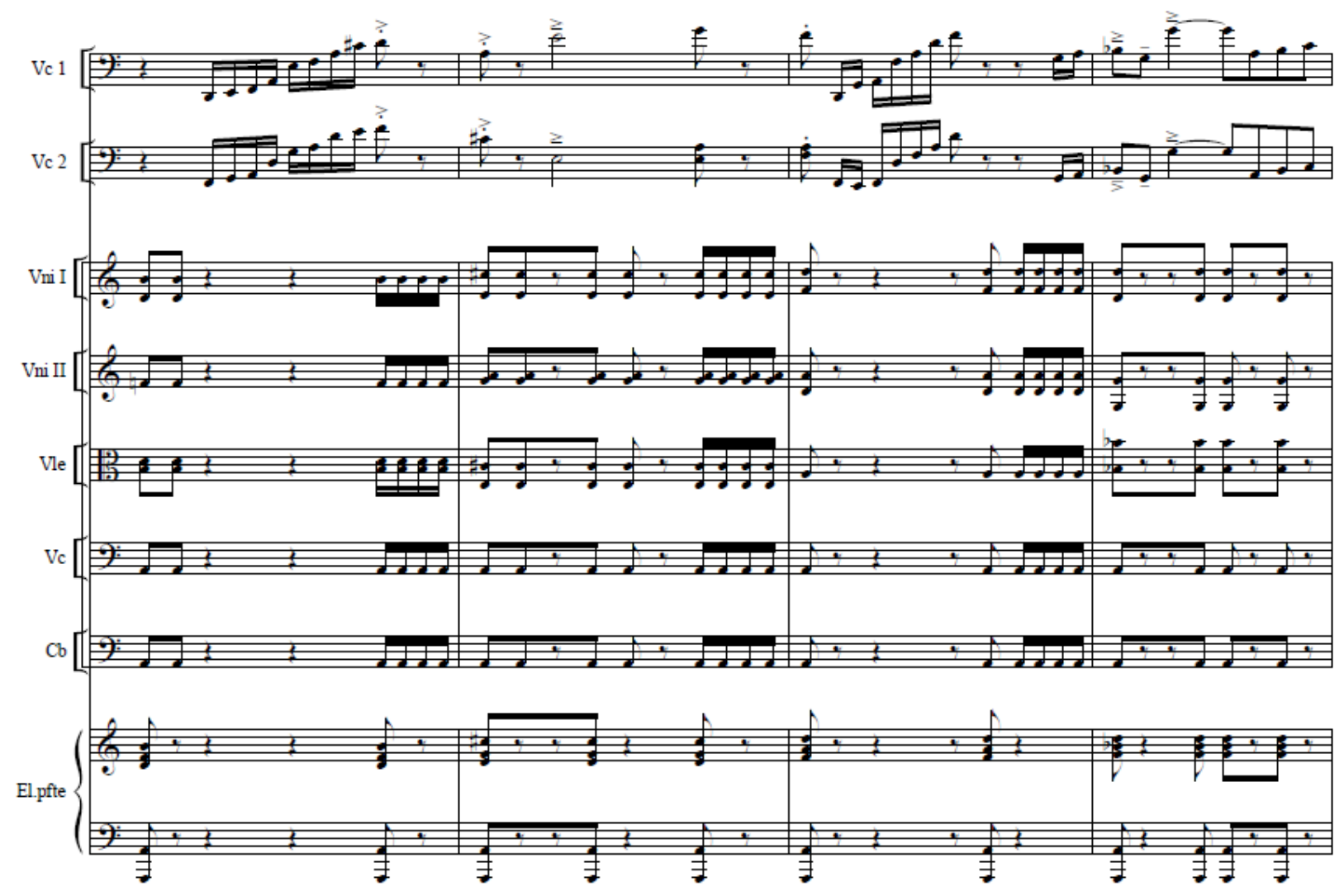

Премда се у делу састају различите музичке прошлости, чини се да је барокна најдоминантнија. Али није реч просто о поновном враћању необарокном компоновању, као што је то било актуелно почетком 20. века у западној Европи. Према мишљењу француског теоретичара уметности Ги Скарпете (Guy Scarpetta) реч је о томе да ми „живимо време барока“, ${ }^{15}$ те да се може говорити о повратку „барокне црте у само средишта модерног стваралаштва”. ${ }^{16}$ Барок, наиме, уводи „фантастично олакшање [...] општу игру и произвољности [...] свет у којем је маска истинитија од лица које скрива [...] где је наличје декора један други декор“. ${ }^{17}$ Барок, такође, репрезентује време у којем се „илузија означава као илузија, где се признаје постојање представе, удвостручавање, где оно што се представља већ припада реду представа, где се са друге

\footnotetext{
${ }^{15}$ Gi Skarpeta, Povratak baroka, Novi Sad, Svetovi, 1988, 10.

${ }^{16}$ Ibid., 10.

${ }^{17}$ Ibid., 21.
} 
стране фикције увек налази друга фикција [...]". ${ }^{18}$ Коришћење друштвених мрежа као што су Facebook или Инстаграм данас, на којима се експонирају садржаји који махом представљају 'најбољи' део личности која профил креира, обожавање тела уз драматичан раст броја хирурушких интервенција којима се повећавају или мењају његови делови, коришћење претераних украса, вештачких трепавица, вештачких обрва, гардеробе у којој су циркони и дијаманти врхунац украшавања - све то говори о друштву „хипертеатралности“ које се скрива иза кулиса својих измишљених стварности у којем се „против илузује бори самим поступцима стварања илузије”. ${ }^{19}$ И не само то. Екстремно (јавно) истицање осећања, спектакли најразличитијих врста у којима се „види оно што је добро, а добро је оно што се види,“20 сведоче о једном новом разумевању емоција, о потреби да се оне 'оголе' до граница издржљивости, посебно у медијима. Управо такво „падање у ватру, осећање подрхтавања, немира, одушевљења, узбуђења“ француски научник ишчитава у барокној уметности, истичући код ње склоност ка „неумерености, некаквој вртоглавици која се директно обраћа телу и чије би се дејство могло означити термином који је истовремено светован и светачки - термином екстаза“. ${ }^{21}$ Оно што је у тој екстази необично јесте што она није 'природна' већ је проузрокована игром облика, кодова, стилова - уметничком вештином. ${ }^{22}$ Управо ту игру кодова препознаје и примењује Драгана Јовановић постижући ефекат поистовећивања са културом барока, са оним познатим и препознатим заогрнутим заједничком бењаминском ауром, али сада ауром савремености која јој даје изванредну слободу интерпретације. Или како каже Томас Бернхард „није ствар у томе да се прича развије, него да се прича увије“. ${ }^{23}$ Додатна аргументација за оваква тумачења Concerta dragonesea даје амерички научник Грег Ламберт (Gregg Lambert). Повратак барока овај амерички научник уочава и тамо где барока никада није било, у острвским земљама, на Карибима, на просторима који су имали своју аутохтону културу и, у оквиру ње, своју музичку традицију независну од европске или барокно-европске. Ламбертова оријентација ка бароку као „глобалном феномену у савременом свету“24 због чега тражи да се о њему говори у множини (,there are many baroques“‘25), објашњава зашто публика из различитих делова света данас 'расположено' перципира савремена дела ослоњена на барокну поетику. Има нешто - сматра Ламберт - што чињеници да се барок вратио даје неки утисак 'свевремености' коју треба захвалити напуштању линеарног поимања историје и теорији о убрзању времена које дозвољава кретање 'кроз њега' у свим правцима.

Не треба сметнути са ума да се барок 'умешао' и у популарну музику друге половине XX века. Нумере In my life састава Битлси (Beatles), A Whiter Shade of Pale групе Прокол Харам (Procol Harum) или Angel in my Heart Мика Џегера (Mick Jagger)

\footnotetext{
${ }^{18}$ Ibid., 17.

${ }^{19}$ Ibid., 16.

${ }^{20}$ Guy Debord, Theory of Spectacle

shttp://www.antiworld.se/project/references/texts/The_Society\%20_Of\%20_The\%20_Spectacle.pdf

${ }^{21}$ Gi Skarpeta, op. cit., 19.

22 Ibid.

${ }^{23}$ Tomas Bernhard, Brisanje. Raspad, Beograd, Lom, 2014.

${ }^{24}$ Gregg Lambert, The Return of the Baroque in Modern Culture, London, Continuum, 2004, 23.

25 Ibid.
} 
на различите начине позивају на елементе барокног стила, чиме указују на тежњу популарне културе да апсорбује елементе високе и ниске културе и понуди 'решења' која - како истичу и енглески теоретичари културе односно културалисти Хол (Hall), Фиск (Fiske) и Вилијамс (Williams) - изражавају креативност тренутног стања културе, а не нешто случајно, 'мање вредно' и ефемерно.

Concerto dragonese Драгане Јовановић представља управо такав креативни резултат у којем се познатим (барокним) средствима јасног тоналитета, живог ритма и богатог мелодијског потенцијала постиже комуникација најпре између извођача, а потом и публике, и то не због тежње за техничким перфекционизмом захтевних деоница, већ управо због оне „радости звучног деловања“, које је истакла Роксанда Пејовић.

\section{Цитирана дела}

Bernhard, Tomas: Brisanje. Raspad. Beograd: Lom, 2014.

Crnjanski, Nataša: Prokofjev i muzički gest. Novi Sad: Akademija umetnosti, 2014.

Debord, Guy: Theory of Spectacle internet link

shttp://www.antiworld.se/project/references/texts/The_Society\%20_Of\%20_The\%20_Spectac le.pdf

Eliot, Tomas Stern: Tradicija i individualni talenat. Eseji. Beograd: Službeni glasnik, 2017.

Lambert, Gregg: The Return of the Baroque in Modern Culture. London: Continuum, 2004.

Pejović, Roksanda: Barokni koncert. Beograd: Nolit, 1981.

Prodanov, Ira: Istorija muzike 20. veka. Novi Sad: Akademija umetnosti, 2013.

Prodanov, Ira, Crnjanski, Nataša i Sovtić Nemanja: Mixed Choir and Symphonu Orchestra of the Academy of Arts University of Novi Sad. Novi Sad: Akademija umetnosti, 2019.

Skarpeta, Gi: Povratak baroka. Novi Sad: Svetovi, 1988.

Swain, Joseph P.: Musical Languages. New York: W. W. Norton, 1997. 